\title{
Emotional Intelligence and Leadership Efficacy of University Student Leaders
}

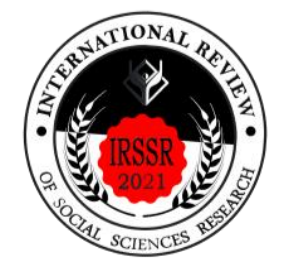

\author{
${ }^{1}$ Hanna Jane H. Aquino, ${ }^{1}$ Kerstine Jane Orozco \& ${ }^{2}$ Portia R. Marasigan
}

\begin{abstract}
The study aimed to determine the relationship between the emotional intelligence and leadership efficacy of the members of student body organization in Laguna State Polytechnic UniversitySan Pablo City Campus (LSPU-SPCC). Through descriptive correlational research method, 80 student-officers were chosen using stratified random sampling. The research instrument was used to measure the respondents' emotional intelligence and their level of leadership efficacy as to adaptability, personal skills, positivity, flexibility, and communication skills. To statistically analyze the data, Pearson $r$ was used. The study findings showed that students have high level of emotional intelligence, high level of leadership efficacy as to flexibility and very high level of leadership efficacy as to adaptability, personal skills, positivity, and communication skills. Furthermore, there was no significant relationship between the profile of the respondents and their emotional intelligence. Similarly, no significant relations were recorded on the profile and leadership efficacy. However, there was significant relationship between emotional intelligence and leadership efficacy of the respondents. The results could serve as inputs to institutional leadership programs.
\end{abstract}

Keywords:

Emotional Intelligence, Leadership Efficacy, Emotions, Leadership

Suggested Citation: Aquino, H.H., Orozco, K. \& Marasigan, P.R. (2021). Emotional Intelligence and Leadership Efficacy of University Student Leaders. International Review of Social Sciences Research, Volume 1 Issue 4, pp. 1- 23.

\footnotetext{
About the authors:

${ }^{1}$ Students, Laguna State Polytechnic University, Philippines

${ }^{2}$ Associate Professor 5, Laguna State Polytechnic University, Philippines
} 


\section{Introduction}

Emotions play an important role for effort that people demonstrate psychological health, and moods. These emotions are woven into every interaction that influence how people react to challenges and opportunities, determine whether to collaborate to resolve conflict, and prompt willingness to forgive others. As the emotional intelligence (EI) has the capacity to be aware of, to control, and to express these emotions, it also enables every person to handle interpersonal relationships judiciously and empathetically. Thus, is serves as basis of any personal decision, problem solving and judgment, which are necessary values of a leader.

George (2000) points out that emotionally intelligent leader can promote effectiveness at all levels in organizations. It gives them the ability to understand others, their emotions, actions as well as behavior towards them. It also enables leaders make smart decisions to bring out the best in people. Studies on emotional intelligence suggests that moods and feelings are linked to actions and thinking process. Consequently, the skills coupled with emotional intelligence make an effective leader. These may also include the ability to inspire others, personal integrity, communication skills and comfort with building relationships, among others. Accordingly, a leader must possess two mental processes: thinking and feeling to be an effective leader to their followers. As leader delegates or influences others to attain specified objectives, they can be a driver of organizational success.

One main factor of an individual's ability to identify and control feelings, as well as other people's feelings, both individually and in groups, is through emotional intelligence. When leading an organization, it is important to gain the trust of every member. If a leader cannot understand other people emotionally, then it is impossible for someone to be an effective leader. As such, leadership efficacy is the ability of an individual's skill associated with the level of confidence in leading other people. According to Humphrey (2002), leadership is an intrinsically emotional process, whereby leaders recognize followers' emotional states, attempt to evoke emotions and seek to manage followers' emotional states accordingly. Thus, leaders set the tone of their organization (Landry, 2019). If they lack emotional intelligence, it could have more far-reaching consequences, resulting in lower employee engagement and a higher turnover rate. In addition, an effective leadership 
involve social interaction that defines leader's ability to control their followers. It is a premise that organizations need to develop the leaders' emotional intelligence to manage effectively their own emotions in decision-making.

In this context, this study argues on the relationship between emotional intelligence and leadership efficacy. As such, it aims to correlate the emotional intelligence and leadership efficacy of the members of student body organization in LSPU-SPCC. Specifically, it sought to assess the level of emotional intelligence, level of efficacy in terms of adaptability, personal skills, positivity, flexibility and communication skills, significant relationship between the demographics and emotional intelligence and leadership efficacy and the relationship between the emotional intelligence and leadership efficacy.

\section{Literature review}

\subsection{Emotional Intelligence}

According to Palaganas (2018), emotions are intrinsically linked to humanity, which play a significant role in determining the acts within the environment. People with high levels of emotional intelligence are naturally capable of achieving their own sentiments, perceiving and expressing themselves, forming and maintaining social relationships, coping with stressful challenges, and making personal decisions that ensure good outcomes. Effective people not only have the technical skills to perform their roles, but more importantly, demonstrate emotional intelligence (Batool, 2013).

In terms of leadership, EI is manifested in the way a person handles interpersonal relationships, steers organizational performance, and influences organizational culture. It also encompasses wide-ranging leadership functions that go beyond technical skills (Arguelles, 2020). Emotionally intelligent leaders can use their social skills to inspire and persuade this category of followers to adopt the proposed change and strive to contribute efficiently toward achieving the organizational goal (Srivastava, 2013). According to Bipath (2008), it is an essential skill for leadership effectiveness, and a predictor of superior performance. By 
recognizing the concerns of individual members, emotionally intelligent leaders use their social skills to convince those who seem reluctant to participate in the change efforts.

The EI is a vital factor for having success in social institutions, because it shows how an individual applies knowledge to different circumstances in life (Ocampo, 2019). As argued by Srivastava (2013), emotionally intelligent leaders can use their social abilities to motivate and persuade group of followers to embrace the suggested change and work diligently toward the organization's goal. These leaders use their social abilities to persuade individuals who are hesitant to participate in change attempts by recognizing their members' worries. Furthermore, such leaders are sensitive to diversity, which is a challenge in today's workplace. According to Foltin and Keller (2012) as cited by Issah and Zimmerman (2016), these type of leaders know and therefore create an environment of open communication for those to be affected by the change to contribute in analyzing the present situation of the organization and to share in the future desired state of the organization. In addition, they recognize that the reaction of the change recipients is a reflection of the underlying fear and uncertainty (Foltin \& Keller, 2012).

According to Castillo (2005), a leader must have high emotional intelligence to develop a high level of collective emotional health in his or her people. One cannot give or develop something, which one does not have or only have a meager supply of. A highly emotionally intelligent leader is likely to be successful in leading his/her organization through whatever crisis they may be confronted with. As explained by Zoller and Pieston (2014), emotional intelligence is about handling relationships, reading and managing nonverbal messages and cues, and being able to control emotions in times of struggles.

\subsection{Components of Leadership Efficacy}

Adaptability. Nelson et al. (2010) define adaptability as a "functional change (cognitive, behavioral, and/or affective) in response to actual or correctly anticipated alterations in environmental contingencies". Therefore, a person can foresee and counteract any reluctant behavior from teammates. According to Bester (2014), adaptive leaders respond quickly to change, organize their team to generate solutions to new problems, and lead performers who perform well under conditions of uncertainty. Heifetz (2018) stated that 
the adaptive leader understands that change can be a painful process. Therefore, he or she can foresee and counteract any reluctant behavior from teammates.

Personal Skills. Fulton (2019) describes student-leaders as someone who understand the objective and driven to get there. They desire personal success and intrinsically set their own goals beyond the ones set. The success of a leader does not necessarily depend on traits, but the working relationship between the leader and other group members, and changing situations. According to Doyle (2021), effective leaders have the ability to communicate well, motivate their team, handle and delegate responsibilities, listen to feedback, and have the flexibility to solve problems in an ever-changing workplace. Moreover, Lavery and Hine (2013) assert that student-leaders acquire skills such as time management, organization, interpersonal communication, decision-making, public speaking, and conflict resolution amongst others. Students who build effective skills will be able to grow into strong and effective leadership practices as they continue to mature. According, Fallon et al. (2011), found that successful leadership needs a systematic and constant exercise as well as a long process and procedure to enhance leadership skills. Thus, to work in the twenty-first century, the preparation is needed by now. A leader should show eagerness, a solid determination, and self-confidence to achieve the goals and engage with the workers to assist them to the success and provide them an opportunity of authorization and relaxation at the workplace.

Positivity. Reh (2020) describes leaders as positive out of necessity. They have to be positive if they are going to successfully inspire and motivate their team toward a goal. Moreover, Youssef-Morgan and Luthans (2013), argue that positivity is crucial for leaders in challenging times. Positive leaders focus on an overall positive treatment of their followers. Cameron (2013) adds that positive leadership practices promote a heliotropic effect, helping people to move toward the positive.

Flexibility. According to Kagame (2021), flexibility is an increasingly important trait in a rapidly changing economic and social environment. Flexible leaders are those who can modify their style or approach to leadership in response to uncertain or unpredictable circumstances. In addition, flexible leaders can adapt to changes as they come. They can revise their plans to incorporate innovations and overcome challenges, while still achieving their goals. 
Communication Skills. According to Root (2018), effective leadership demands interacting with people. This requires communicating in a manner that goes beyond just relaying information. The most successful leaders inspire others, build connections between people, and create alignment throughout the organization. Moreover, Landry (2019) asserts that effective communication is vital to gain trust, align efforts in the pursuit of goals, and inspire positive change. When communication is lacking, important information can be misinterpreted, causing relationships to suffer and, ultimately, creating barriers that hinder progress. According to Gaubatz and Ensminger (2017), even in the situations where members of the organization are satisfied with the status quo and therefore become resistant to the idea of change, the communication skills of the leader are equally essential to create dissatisfaction with the status quo among the members.

\subsection{Relationship between Emotional Intelligence and Leadership Efficacy}

The study conducted by Batool (2013) found positive significant relationship between leadership style and emotional intelligence. As emotional intelligence has become increasingly popular as a measure for identifying potentially effective leaders, it also become a tool for developing effective leadership skills. Accordingly, emotional intelligence and leadership skills are two prevalent skills linked to successful performance in the workplace and effective leadership (Brown, 2014; Miller, 2015). In addition, people who promote emotional intelligence showed that it brought positive outcome in their respective careers, because they influenced each other as they stayed attuned and connected together (Ishmaill et al., 2012; Kannaiah \& Shanthi, 2015).

Several studies had established a clear positive association between EI and leadership. For instance, the cross-sectional study of Obomanu (2018) proved that there were positive and statistically significant relations between the EI and leadership effectiveness of bankers in Africa. The study posits that leaders with high level of EI achieve personal and organizational effectiveness. Similar findings were recorded by Nabih, et al. (2016) on the EI as predictor of leadership effectiveness. The review of empirical studies conducted by Baba and Siddiqi (2018) also showed that organizations with emotionally intelligent leaders have productive, motivated, efficient and committed staff. The extent of influence is similar to any field. For example, the study of Koh and O'Higgins (2018 found that the cadet officers of 
Singapore Air Force have EI and leadership effectiveness with positive statistical relationship. Meanwhile, the study of Gomez-Leal, et al. (2021) on the EI and leadership in schools had the same findings. It was concluded that EI is key for the effective leadership of school leaders. In addition, Ainomugisha (2018) asserts that emotionally intelligent leaders foster safe environments, where employees feel comfortable to take calculated risks, suggest ideas and to voice their opinions. In such safe environments, working collaboratively is not just an objective, but it gets woven into the organizational culture as whole. When a leader is emotionally intelligent, they can use emotions to drive the organization forward. Leaders often have the responsibility of effecting any necessary changes in the organization, and if they are aware of others' possible emotional reactions to these changes, they are able to plan and prepare the most optimal ways to make them.

\section{Methodology}

The study used descriptive correlational design to ascertain and to explain further the emotional intelligence and leadership efficacy of the officers of the student body organizations in LSPU-SPCC.

The respondents of the study are 80 student-officers of different organizations in the university selected using quota sampling. The study aims to collect 10 samples from the different departments. The criteria considered for the selection of the respondents include: he or she must be an officer of any student body organization; currently registered or enrolled during the conduct of the survey; and willing to participate in the study. The profile of the respondents includes: majority of them were 20 to 22 years old $(78.75 \%), 17.50 \%$ of them were 18 to 19 years old, and the remaining 3.75\% were 23-25 years old; majority of them were male (52.50\%); and majority of the respondents were in their 3rd year (43.75\%), $38.75 \%$ were in their 2 nd year, $15 \%$ were in 1 st year and the remaining $2.50 \%$ were in their 4 th year.

The respondents were chosen from the College of Arts and Sciences, College of Computer Studies, College of Engineering, College of Business Management and Accountancy, College of Hospitality Management and Tourism, College of Teacher 
Education, College of Criminal Justice and Education, and College of Information Technology.

The study used 3 data gathering instruments namely: Information sheets, to determine the profile of the students; Emotional Intelligence Questionnaire, adapted from Daniel Goleman, to determine the level of emotional intelligence; and Test on Leadership Efficacy, to determine the level of leadership efficacy. All these instruments assessed the study variables which are answerable by a 4-scale Likert style indicators.

Due to the on-going travel bans and restrictions, the data gathering was conducted online. The "new normal" for survey research was done through Google forms distributed through online messenger application such as Facebook and e-mails. The form include a thorough explanation on the purpose of the study. All the respondents were given sufficient time to answer the given questionnaire. The respondents were aware on the confidentiality of their answers.

The data gathered were calculated using weighted mean, to measure the average of the scores of the test taken by the respondents, frequency and percentage distribution, to know the number of occurrences of a repeating event per unit of time, and Pearson-Product Moment Correlation (Pearson r), to measure the correlation between the two variables.

\section{Findings and Discussion}

Table 1 shows the level of student-leaders' emotional intelligence. From the 25 indicators of EI, the overall mean was 3.40 interpreted as 'High'. The data proved that the students' self-assessment indicated a high level of EI. Few of the indicators were assessed with a very high level. This signifies that the student-leaders are emotionally intelligent in handling cases and situations related to their position in the student organization. 
Table 1

Level of Student-Leaders' Emotional Intelligence

\begin{tabular}{|c|c|c|c|}
\hline Indicator & Mean & SD & Interpretation \\
\hline $\begin{array}{l}\text { 1. Able to describe how your own feelings affect your own } \\
\text { actions. }\end{array}$ & 3.37 & 0.62 & High \\
\hline 2. Acts appropriately even in emotionally charged situations. & 3.23 & 0.64 & High \\
\hline 3. Understands another person's motivation. & 3.62 & 0.56 & High \\
\hline 4. Understands subtle feelings of others. & 3.46 & 0.59 & High \\
\hline 5. Tries to resolve conflict instead of allowing it to fester. & 3.41 & 0.63 & High \\
\hline 6. Understands social networks. & 3.46 & 0.59 & High \\
\hline 7. Loses composure when under stress. & 2.88 & 0.81 & High \\
\hline 8. Controls impulses appropriately in situations. & 3.21 & 0.61 & High \\
\hline 9. Understands others by listening attentively. & 3.57 & 0.52 & Very high \\
\hline 10. Can recognize emotions as they experience them. & 3.51 & 0.61 & Very high \\
\hline $\begin{array}{l}\text { 11. Aware of the connection between what is happening and } \\
\text { your own feelings. }\end{array}$ & 3.47 & 0.57 & High \\
\hline 12. Acknowledges own strengths and weaknesses. & 3.60 & 0.58 & Very high \\
\hline $\begin{array}{l}\text { 13. Sees the positive in people, situations and events more } \\
\text { often than the negative. }\end{array}$ & 3.47 & 0.57 & High \\
\hline 14. Enjoys organizing groups. & 3.50 & 0.57 & Very high \\
\hline 15. Avoids conflict and negotiations. & 3.27 & 0.69 & High \\
\hline $\begin{array}{l}\text { 16. Ask for others' feedback on the things that have been } \\
\text { done and can be improved. }\end{array}$ & 3.70 & 0.48 & Very high \\
\hline 17. Can recognize easily if they are stressed. & 3.26 & 0.65 & High \\
\hline $\begin{array}{l}\text { 18. Seeks to improve oneself by setting measurable and } \\
\text { challenging goals. }\end{array}$ & 3.45 & 0.59 & High \\
\hline $\begin{array}{l}\text { 19. Tries to resolve conflict by openly talking about } \\
\text { disagreement with those involved. }\end{array}$ & 3.33 & 0.72 & High \\
\hline 20. Excellent at empathising with someone else's problem. & 3.27 & 0.67 & High \\
\hline $\begin{array}{l}\text { 21. Understands other's perspectives when they are different } \\
\text { from own perspective }\end{array}$ & 3.43 & 0.63 & High \\
\hline 22. Works well in teams by being respectful of others & 3.51 & 0.61 & Very high \\
\hline 23. Reasons for disagreements are easy to understand. & 3.22 & 0.71 & High \\
\hline 24. Sees possibilities more than the problems. & 3.48 & 0.55 & High \\
\hline $\begin{array}{l}\text { 25. Avoids getting impatient or showing frustration } \\
\text { inappropriately. }\end{array}$ & 3.35 & 0.63 & High \\
\hline Over all Mean & 3.40 & 0.64 & High \\
\hline
\end{tabular}

Legend: $3.50-4.00=$ always $/$ very high, $2.50-3.49=$ often $/$ high

$1.50-2.49=$ seldom $/$ low, $1.00-1.49=$ never $/$ very low

Indicator 7 has the lowest mean score of 2.88 and the standard deviation of 0.66 with an interpretation of high level, which implies that the respondents often lose composure when they are under stress. It means that they are not sure how to manage if they are under stress 
especially when they have a lot of tasks to focus on. Most of the time, they cannot handle the pressure that they are feeling during stressful situations. Indicator 16 has the highest mean score of 3.70 and the standard deviation of 0.48 with an interpretation of high level, which implies that the respondents often ask others feedback on the things that have been done and can be improved. It gives them confidence to do their work when other members approve of them and they also learn from it to improve themselves when others disapprove. They can deal with difficult situations and can build better relationships.

With an overall weighted mean of 3.45, standard deviation of 0.64 and an interpretation of high level, it implies that the respondents often develop their emotional intelligence in being a member of a student body organization. It is easy for them to remain calm in every stressful situation and can resolve any conflicts that may happen. They can build a good relationship and trust with other people by being aware of others and also their own emotions. If members lack emotional intelligence, there could be a lot of consequences and they will have a hard time focusing on their tasks. As stated by Moore (2009), leaders can use emotional information to build trust and secure cooperation, display empathy to employees, social awareness, develop collaboration, understand the loss that people experience during the change process and display their skills in addressing issues and solving problems.

Table 2 shows the respondents' leadership efficacy in terms of adaptability. Indicator 1 has the lowest mean score of 3.36. The standard deviation of 0.62 with an interpretation of high level implies that the respondents are often able to foster a good interpersonal relationship towards their team members. It means that the respondents do not have any interpersonal relationship towards their team members most of the time since they tend to focus a lot on their own tasks. They give most of their time in dealing with their organization. Indicator 2 has the highest mean score of 3.65. The standard deviation of 0.50 with an interpretation of very high level means that the respondents always consider the suggestions of team members for the improvement of the organizational goals. It means that the respondents have eagerness to gain knowledge from other members. They accept other members' opinions to improve themselves as a member of the student body organization. 
Table 2

Leadership Efficacy as to Adaptability

\begin{tabular}{|c|c|c|c|}
\hline Indicator & Mean & SD & Interpretation \\
\hline $\begin{array}{l}\text { 1. I am able to foster a good interpersonal } \\
\text { relationship towards my team members. }\end{array}$ & 3.36 & 0.62 & High \\
\hline $\begin{array}{l}\text { 2. I consider the suggestions of my team members } \\
\text { for the improvement of the organizational goals. }\end{array}$ & 3.65 & 0.50 & Very high \\
\hline $\begin{array}{l}\text { 3. I actively listen to my team members involving } \\
\text { the need in decision making. }\end{array}$ & 3.62 & 0.60 & Very high \\
\hline $\begin{array}{l}\text { 4. I encourage my team members to be enthusiastic } \\
\text { towards work. }\end{array}$ & 3.57 & 0.56 & Very high \\
\hline $\begin{array}{l}\text { 5. I seek opportunities that can enhance my team } \\
\text { member's leadership skills. }\end{array}$ & 3.56 & 0.57 & Very high \\
\hline $\begin{array}{l}\text { 6. I consider the ideas of my team members in } \\
\text { planning events in an organization. }\end{array}$ & 3.63 & 0.53 & Very high \\
\hline $\begin{array}{l}\text { 7. I emphasize the importance of having a collective } \\
\text { sense of mission. }\end{array}$ & 3.60 & 0.51 & Very high \\
\hline $\begin{array}{l}\text { 8. I consider the freedom of my team members that } \\
\text { can adapt to current issues and events. }\end{array}$ & 3.62 & 0.53 & Very high \\
\hline $\begin{array}{l}\text { 9. I encourage my team members to improve their } \\
\text { skills. }\end{array}$ & 3.56 & 0.59 & Very high \\
\hline $\begin{array}{l}\text { 10. I encourage my team members to seek } \\
\text { opportunities, to discover and improve their skills. }\end{array}$ & 3.56 & 0.59 & Very high \\
\hline Over all Mean & 3.57 & 0.56 & Very high \\
\hline
\end{tabular}

The overall weighted mean of 3.57 and a standard deviation of 0.56 was interpreted as very high level. It can be implied that the respondents can always adapt in any situation that they may face. Being adaptable makes an organization or a team more productive and effective. Their teamwork boosts creativity, gives support and improves productivity. According to Calarco (2020), adaptable leaders recognize that leading and managing change is an imperative of today's world, and they urgently seek new ways to solve novel problems, master new skills, and embrace new challenges with grounded innovation.

Table 3 shows the respondents' leadership efficacy in terms of personal skills. Indicator 3 has the lowest mean of 3.48 and a standard deviation of 0.72 with an interpretation of high level, which means that the respondents are often reliable in decision making. It means that the respondents sometimes find it difficult in making decisions since their organization depends on it. Decision making is very important in an organization since it also results in being productive in accomplishing daily tasks. Indicator 2 has a mean of 
3.81 and a standard deviation of 0.42 with an interpretation of very high level, which means that the respondents always respect and understand other perceptions and beliefs in an organization. They consider other members' opinions to avoid any conflict and to build trust in each other. An effective team member also understands others to achieve their goals and be responsible.

\section{Table 3}

Leadership Efficacy as to Personal Skills

\begin{tabular}{|c|c|c|c|}
\hline Indicators & Mean & SD & Interpretation \\
\hline 1. As a leader, I am responsible for my duties. & 3.75 & 0.46 & Very high \\
\hline $\begin{array}{l}\text { 2. As a leader, I respect and understand other } \\
\text { perceptions and beliefs in an organization. }\end{array}$ & 3.81 & 0.42 & Very high \\
\hline $\begin{array}{l}\text { 3. As a leader, I am reliable in my decision } \\
\text { making. }\end{array}$ & 3.48 & 0.72 & High \\
\hline $\begin{array}{l}\text { 4. As a leader, I maintain my goal and perspective } \\
\text { in a current event. }\end{array}$ & 3.66 & 0.50 & Very high \\
\hline $\begin{array}{l}\text { 5. As a leader, I am responsible to trust my team } \\
\text { members. }\end{array}$ & 3.75 & 0.49 & Very high \\
\hline $\begin{array}{l}\text { 6. As a leader, I am able to develop the ability of } \\
\text { my teammates to lead in organization. }\end{array}$ & 3.61 & 0.56 & Very high \\
\hline $\begin{array}{l}\text { 7. As a leader, I am responsible to share the goals } \\
\text { and objectives to my teammates in an } \\
\text { organization. }\end{array}$ & 3.70 & 0.48 & Very high \\
\hline $\begin{array}{l}\text { 8. As a leader, I am responsible for knowing the } \\
\text { weaknesses of an organization. }\end{array}$ & 3.62 & 0.53 & Very high \\
\hline $\begin{array}{l}\text { 9. As a leader, I am able to avoid wasting time in } \\
\text { an organization during current events. }\end{array}$ & 3.52 & 0.55 & Very high \\
\hline $\begin{array}{l}\text { 10. As a leader, I am responsible to share to my } \\
\text { teammates the action plan of an organization. }\end{array}$ & 3.70 & 0.46 & Very high \\
\hline Over all Mean & 3.66 & 0.53 & Very high \\
\hline
\end{tabular}

With an overall weighted mean of 3.66, a standard deviation equivalent to 0.53 and an interpretation of very high level, it can be implied that the respondents always apply their personal skills to be an effective member of the student body organization. It means that the respondents apply their personal skills effectively to have good teamwork. By having good teamwork, the organization will be successful in every task they may face. According to Gilley, et al. (2009), for effective organizational change leaders must have different skills or behaviors such as leader's ability to motivate, communicate, and build team, by adopting these skills a leader will become an effective leader. 
Table 4

Leadership Efficacy as to Positivity

\begin{tabular}{lccc}
\hline \multicolumn{1}{c}{ Indicators } & Mean & SD & Interpretation \\
\hline $\begin{array}{l}\text { 1. As a student leader, I can motivate my team members } \\
\text { by sharing our vision. }\end{array}$ & 3.55 & 0.54 & Very high \\
2. As a student leader, I maintain my enthusiasm among & 3.61 & 0.51 & Very high \\
my team members and in an organization. & & & \\
3. I generally build solid relationships with those I work & 3.61 & 0.51 & Very high \\
with. \\
$\begin{array}{l}\text { 4. As a student leader, I make an acknowledgement to } \\
\text { my team members about their performance. }\end{array}$ \\
$\begin{array}{l}\text { 5. I maintain being open-minded to a current event in an } \\
\text { organization. }\end{array}$ & 3.66 & 0.52 & Very high \\
$\begin{array}{l}\text { 6. As a student leader, I can motivate my team members } \\
\text { to achieve our goals in an organization. }\end{array}$ & 3.57 & 0.54 & Very high \\
$\begin{array}{l}\text { 7. As a student leader, I appreciate the extra efforts of } \\
\text { my team members in current events. }\end{array}$ & 3.72 & 0.50 & Very high \\
$\begin{array}{l}\text { 8. As a student leader, I consider the ethical } \\
\text { consequences of every decision. }\end{array}$ & 3.63 & 0.53 & Very high \\
$\begin{array}{l}\text { 9. As a student leader, I maintain to help my team } \\
\text { members to develop their strength. }\end{array}$ & 3.55 & 0.52 & Very high \\
$\begin{array}{l}\text { 10. I maintain to support my team members with their } \\
\text { ideas that are needed in the organization. }\end{array}$ & 3.57 & 0.54 & Very high \\
\hline$\quad$ Over all Mean & 3.66 & $\mathbf{0 . 5 2}$ & Very high \\
\hline \begin{tabular}{l}
$1.50-2.49=$ seldom / low, $1.00-1.49=$ never $/$ very low \\
\hline
\end{tabular} & & \\
\hline
\end{tabular}

Table 4 shows the respondents' leadership efficacy in terms of positivity. Indicator 1 has the lowest mean score of 3.55 and a standard deviation of 0.54 with an interpretation of very high. It means the respondents always motivate their team members by sharing their vision. It also means that the respondents sometimes find it difficult to give their support to other members especially when they are in a stressful situation. They tend to focus on motivating their own self especially when the members only focus on their own tasks. Indicator 9 also has a lowest mean score of 3.55 and a standard deviation of 0.52 with an interpretation of very high level. It means that the respondents always help their team members to develop their strength. It means that the respondents sometimes cannot help other members since they also cannot handle another task to finish. Indicator 7 has the highest mean score of 3.72 and a standard deviation of 0.50 with an interpretation of very high level. It means that the respondents always appreciate the extra efforts of their team members in current events. Appreciating their efforts helps them to boost their confidence and to be more creative. It also gives motivation to them to do more by thinking that their efforts were appreciated by other members. 
The overall weighted mean of 3.66 and a standard deviation equivalent to 0.52 were interpreted as very high level. It can be implied that respondents always choose to be positive in every situation or even a failure and often try to find at least one good thing about the situation. According to Stottlemayer (2002), with a primary source of positive emotions, leaders may build a successful organizational culture.

Table 5

Leadership Efficacy as to Flexibility

\begin{tabular}{|c|c|c|c|}
\hline Indicators & Mean & SD & Interpretation \\
\hline $\begin{array}{l}\text { 1. As a student leader, it is easy for me to manage } \\
\text { my responsibilities. }\end{array}$ & 3.19 & 0.80 & High \\
\hline $\begin{array}{l}\text { 2. As a student leader. I can focus on the main } \\
\text { planning in the organization event. }\end{array}$ & 3.45 & 0.57 & High \\
\hline $\begin{array}{l}\text { 3. I can quickly find solutions to problem } / \mathrm{s} \text { raised in } \\
\text { the organization. }\end{array}$ & 3.26 & 0.62 & High \\
\hline $\begin{array}{l}\text { 4. It is easy for me to administer the announcement } \\
\text { to a student in an organization. }\end{array}$ & 3.45 & 0.66 & High \\
\hline $\begin{array}{l}\text { 5. As a student leader, it is easy for me to make a } \\
\text { time table to manage my time. }\end{array}$ & 3.24 & 0.68 & High \\
\hline $\begin{array}{l}\text { 6. As a student leader, it is easier for me to find } \\
\text { solutions than complaining. }\end{array}$ & 3.41 & 0.57 & High \\
\hline $\begin{array}{l}\text { 7. It is easy for me to gather my team members } \\
\text { during meetings. }\end{array}$ & 3.23 & 0.71 & High \\
\hline $\begin{array}{l}\text { 8. As a student leader, I often find other ways by } \\
\text { achieving our objectives in an organization. }\end{array}$ & 3.46 & 0.57 & High \\
\hline $\begin{array}{l}\text { 9. It is easy for me to multitask during current } \\
\text { events. }\end{array}$ & 3.29 & 0.68 & High \\
\hline $\begin{array}{l}\text { 10. As a student leader, I can make others' time } \\
\text { tables to finish their responsibility in an } \\
\text { organization. }\end{array}$ & 3.26 & 0.64 & High \\
\hline Over all Mean & 3.32 & 0.65 & High \\
\hline
\end{tabular}

Table 5 shows the respondents' leadership efficacy in terms of flexibility. Indicator 1 has the lowest mean score of 3.19 and a standard deviation of 0.80 with an interpretation of high level. It means that some of the respondents often easily manage their responsibilities but there are also times they find it hard to manage their responsibilities or their tasks. They cannot handle the work that they have to finish especially when they experience a lot of pressure. Indicator 8 has the highest mean of 3.46 and a standard deviation of 0.57 with an 
interpretation of high level. It means that some of the respondents often find other ways by achieving their objectives in an organization. The respondents always have the eagerness to accomplish their tasks and to serve their organization.

The overall weighted mean of 3.32 and standard deviation equivalent to 0.65 were interpreted as high level. It can be implied that the respondents are often flexible in every task responsibility that they may face. They are ready to respond to changing situations or circumstances. It gives an ability for them to be productive especially during the times that there are changes in a situation. If members can't be flexible in managing their tasks, they will have a hard time finishing all their tasks and responsibilities.

\section{Table 6}

Leadership Efficacy as to Communication Skills

\begin{tabular}{|c|c|c|c|}
\hline Indicators & Mean & SD & Interpretation \\
\hline $\begin{array}{l}\text { 1. I maintain listening first before correcting my team } \\
\text { members. }\end{array}$ & 3.67 & 0.49 & Very high \\
\hline $\begin{array}{l}\text { 2. I choose my words, before saying it to my team } \\
\text { members. }\end{array}$ & 3.61 & 0.60 & Very high \\
\hline $\begin{array}{l}\text { 3. I maintain good communication among my team } \\
\text { members. }\end{array}$ & 3.67 & 0.49 & Very high \\
\hline $\begin{array}{l}\text { 4. I respect the suggestions among my team } \\
\text { members. }\end{array}$ & 3.76 & 0.42 & Very high \\
\hline $\begin{array}{l}\text { 5. I make clarifications with my team members if } \\
\text { there are misunderstandings on a certain task. }\end{array}$ & 3.76 & 0.42 & Very high \\
\hline $\begin{array}{l}\text { 6. I generally build solid communication with my } \\
\text { teammates in an organization. }\end{array}$ & 3.65 & 0.53 & Very high \\
\hline $\begin{array}{l}\text { 7. I maintain to share positive feedback to my } \\
\text { teammates in an organization. }\end{array}$ & 3.67 & 0.47 & Very high \\
\hline $\begin{array}{l}\text { 8. I maintain to speak appropriately to my teammates } \\
\text { during meetings and events in an organization. }\end{array}$ & 3.63 & 0.60 & Very high \\
\hline $\begin{array}{l}\text { 9. I maintain good interaction with my teammates in } \\
\text { an organization. }\end{array}$ & 3.68 & 0.46 & Very high \\
\hline $\begin{array}{l}\text { 10. I maintain to help my teammates during hard } \\
\text { times in current events. }\end{array}$ & 3.73 & 0.43 & Very high \\
\hline Over all Mean & 3.68 & 0.50 & Very high \\
\hline
\end{tabular}

Table 6 shows the respondents' leadership efficacy in terms of communication skills. Indicator 2 has the lowest mean score of 3.61 and a standard deviation of 0.60 with an 
interpretation of very high level. It means that some of the respondents always choose their words, before saying it to their team members. It also implies that there are times negative words are said especially when under pressure but they always choose to be understanding to avoid problems. Indicator 4 has the highest mean score of 3.76 and a standard deviation of 0.42 with an interpretation of very high level. It means that some of the respondents always respect the suggestions of their team members. It gives other members an opportunity to take over some tasks and to be more creative. Indicator 5 also has the highest mean score of 3.76 which means that some of the respondents always make clarifications with their team members if there are misunderstandings on a certain task. Asking for clarifications can help avoid any problems and misunderstanding within the organization.

With an overall weighted mean of 3.68 and standard deviation equivalent to 0.50 , there were interpreted as very high level. It can be implied that the respondents always try to communicate with their other members to build their trust, good relationship and to help other members in doing certain tasks. Being open with all of the members can help in being successful in dealing with their tasks and their organization to be successful.

Table 7

Summary Results of Level of Leadership Efficacy

\begin{tabular}{ccc}
\hline Factors & Mean & Level \\
\hline Adaptiveness & 3.57 & Very High \\
Personal Skills & 3.66 & Very High \\
Positivity & 3.66 & Very High \\
Flexibility & 3.32 & High \\
Communication Skills & 3.68 & Very High \\
\hline Overall Mean & 3.58 & Very High \\
\hline Legend: $3.50-4.00=$ always $/$ very high, $2.50-3.49=$ often $/$ high \\
$1.50-2.49=$ seldom /low, $1.00-1.49=$ never $/$ very low & \\
\end{tabular}

Table 7 shows the summary result of the level of student-leaders' leadership efficacy. Communication skills appear to have the highest mean score of 3.68, which indicates a very high level of leadership efficacy of the respondents. It implies that it is important for the respondents to know how to communicate effectively to every member to build trust and to 
support each other. By communicating, they become aware of what weaknesses and strengths a member possesses. It can also help them in clarifying tasks to avoid any misunderstanding with their members. Moreover, flexibility has the lowest mean score of 3.32 which shows that the respondents still find it hard to manage their responsibilities especially when under pressure. They could not focus on their responsibilities at the same time. Most of them could not handle the pressure that they are experiencing. The overall mean indicates a very high level of leadership efficacy. This confirms that the members of the student body organization have the knowledge, skills and abilities to lead other people that make an organization successful and productive. These data proved that respondents possess the skills that can help them to be an effective member of student body organization.

\section{Table 8}

Test of Relationship between Profile and Emotional Intelligence

\begin{tabular}{cccc}
\hline Variables & r-value & p-value & interpretation \\
\hline Age & -0.191 & 0.092 & not significant \\
Sex & 0.046 & 0.058 & not significant \\
year level & -0.186 & 0.086 & not significant \\
College & 0.048 & 0.060 & not significant \\
\hline Legend: $p<0.05$, significant; $p>0.05$, not significant &
\end{tabular}

As to the relationship between the level of emotional intelligence of the respondents and their profile, the statistical results show that the demographic profile of the respondents do not have any significant relationship to emotional intelligence. Being an emotionally intelligent member of a student body organization does not depend on their age, sex, year level and course. It develops as they grow as a better person and by learning from their experiences, as long as they have the desire to pursue it. It depends on their knowledge and to how they would apply it to their daily life. Therefore, the age, sex, year level, and the college of specialization has no implication of their level of emotional intelligence. The demographic profiles of the student-leaders are not predictors of their level of emotional intelligence. This 
is attributed to the similarity of the responses, which were mostly high and very high selfassessments. The similarity of the self-assessments translated to skewness of the data.

Table 9

Relationship between Profile of the Respondents and Leadership Efficacy

\begin{tabular}{|c|c|c|c|c|c|c|c|c|c|c|}
\hline \multirow[t]{2}{*}{ Variable } & \multicolumn{2}{|c|}{ adaptiveness } & \multicolumn{2}{|c|}{$\begin{array}{l}\text { personal } \\
\text { skills }\end{array}$} & \multicolumn{2}{|c|}{ Positivity } & \multicolumn{2}{|c|}{ flexibility } & \multicolumn{2}{|c|}{$\begin{array}{c}\text { communicat } \\
\text { ion skills }\end{array}$} \\
\hline & $\begin{array}{l}\mathrm{r}- \\
\text { value }\end{array}$ & $\begin{array}{l}\text { p- } \\
\text { value }\end{array}$ & $\begin{array}{l}\mathrm{r}- \\
\text { value }\end{array}$ & $\begin{array}{l}\text { p- } \\
\text { value }\end{array}$ & $\begin{array}{l}\mathrm{r}- \\
\text { value }\end{array}$ & $\begin{array}{l}\text { p- } \\
\text { value }\end{array}$ & $\begin{array}{l}\mathrm{r}- \\
\text { value }\end{array}$ & $\begin{array}{l}\text { p- } \\
\text { value }\end{array}$ & $\begin{array}{l}\mathrm{r}- \\
\text { value }\end{array}$ & $\begin{array}{l}\text { p- } \\
\text { value }\end{array}$ \\
\hline Age & 0.262 & $0.008^{*}$ & -0.134 & 0.127 & 0.117 & 0.102 & 0.070 & 0.081 & -0.003 & $\mathrm{n} / \mathrm{a}$ \\
\hline Sex & 0.000 & $\mathrm{n} / \mathrm{a}$ & 0.131 & 0.120 & 0.000 & N/A & 0.046 & 0.070 & 0.000 & $\mathrm{n} / \mathrm{a}$ \\
\hline year level & 0.164 & 0.153 & 0.004 & 0.052 & 0.336 & $0.02^{*}$ & 0.025 & 0.061 & 0.053 & n/a \\
\hline College & 0.045 & 0.071 & 0.025 & 0.060 & 0.122 & 0.116 & -0.017 & 0.058 & -0.020 & n/a \\
\hline
\end{tabular}

Legend: $p<0.05$, significant; $p>0.05$, not significant

- significant

As to the relationship between the respondents' demographics and leadership efficacy, the results in table 9 show that all demographic variables have no significant relationship to the leadership efficacy, measured in terms of adaptability, personal skills, positivity, flexibility and communication skills. The demographics are not predictors of the level of leadership efficacy. It implies that there are the demographic profiles of the studentleaders do not necessary reflect the level of their leadership efficacy. This again is attributed to the similarity on the self-assessments of the respondents. Similarly, the leadership efficacy is relative to how a person can effectively do their responsibilities, which depends on their eagerness to learn and better leader, not on their profile. These are more intrinsic than extrinsic in nature reflecting that as long as they have the passion to do it and to have the knowledge to guide every person, they can be effective leaders.

Table 10

Relationship between Emotional Intelligence and Leadership Efficacy

\begin{tabular}{cccc} 
Variables & r-value & p-value & Interpretation \\
\hline Adaptiveness & 0.506 & 0.011 & Significant \\
personal skills & 0.432 & 0.029 & Significant \\
Positivity & 0.523 & 0.008 & Significant \\
Flexibility & 0.460 & 0.020 & Significant \\
communication skills & 0.472 & 0.019 & Significant \\
\hline
\end{tabular}

Legend: $p<0.05$, significant; $p>0.05$, not significant 
Table 10 shows the correlation between emotional intelligence and leadership efficacy of the student-leaders. All the indicators of leadership efficacy have statistical significant relationship with the emotional intelligence. The positive relationship implies that the higher the emotional intelligence of the student-leaders the higher their leadership efficacy. This also connotes that the emotional intelligence has positive influence on the leadership efficacy. The statistical results affirmed all the studies supporting the positive significant relations between emotional intelligence and leadership effectiveness (Batool, 2013; Brown, 2014; Miller, 2015; Ishmaill et al., 2012; Kannaiah \& Shanthi, 2015; Obomanu, 2018; Nabih, et al., 2016; Baba \& Siddiqi, 2018; Koh \& O’Higgins, 2018; Gomez-Leal, et al., 2021; Ainomugisha, 2018).

\section{Conclusion}

This study used descriptive correlational design to assess the emotional intelligence and leadership efficacy of the student-leaders in LSPU-SPCC. There were 80 student-leaders chosen as respondents using quota sampling, representing 10 students from the different departments. The three data gathering instruments used were information sheets, Emotional Intelligence Questionnaire, and Test on Leadership Efficacy. The survey was conducted through Google forms and Facebook messenger.

The study revealed high level of student-leaders' emotional intelligence and leadership efficacy as to adaptability, personal skills, positivity, and communication skills. It was further revealed that there was no significant relationship between the demographic profile of the respondents and their emotional intelligence as well as leadership efficacy. However, there was positive correlation between emotional intelligence and leadership efficacy. The results affirm that the emotional intelligence of the student-leaders positively influence their level of leadership efficacy.

As the study has various limitations as to the variables tested and the number of samples, further research could consider re-test or attest the reliability of and validity of the 
results. A wider scope and bigger sample size can prove or disprove the consistency of the results. As to the development of student-leaders, the university may take the results as inputs in the leadership development programs or leadership succession to continuously share the good practices of the students in various departments. The various departments may intensify its campaign for strong emotional intelligence of the students upon assumption of various responsibilities in the university student bodies. It should be noted that leadership development is not a one-way process. The students and the whole academic community help shape the entire studentry.

\section{References}

Ainomugisha, G. (2018). The Importance of Emotional Intelligence in Leadership. https://inside.6q.io/emotionalintelligence-in-leadership/

Baba, M. \& Siddiqi, M. (2018). Emotional Intelligence And Transformational Leadership: A Review Of Empirical Studies. The Business Review, Vol. 22, No. 1

Batool, B (2013). Emotional Intelligence and Effective Leadership. Superior University. https://citeseerx.ist.psu.edu/viewdoc/download?doi=10.1.1.652.8649\&rep=rep1\&type $=\mathrm{pdf}$

Bester, CP (2014). Adaptable Leaders for the South African Army. CDA Press.

Bipath, K. (2008). The emotional intelligence of the principal is essential in the leadership of a functional school. The International Journal of Learning, 15:57-64.

Brown, C. (2014). The Effects of Emotional Intelligence (EI) and Leadership Style on Sales Performance. Economic Insights: Trends and Challenges, Vol. III (LXVI), No.3, pp. $1-14$

Calarco, A. (2020). Adaptable Leadership. Center for Creative Leadership. https://files.eric.ed.gov/fulltext/ED606779.pdf

Cameron, K. (2013). Practicing positive leadership: Tools and techniques that create extraordinary results. San Francisco, CA: Berrett-Koehler.

Castillo, R. (2015). The Need for Emotionally Intelligent Leaders. Philippine Daily Inquirer. https://business.inquirer.net/186753/the-need-for-emotionally-intelligent-leaders 
Doyle, A. (2021). Important Leadership Skills for Workplace Success. The Balance Careers. https://www.thebalancecareers.com/top-leadership-skills-2063782

Gaubatz, J. A., Ensminger, D. C. (2017). Department chairs as change agents: Leading change in resistant environments. Educational Management Administration and Leadership, 45, 141-163. doi:10.1177/1741143215587307

George, J. M. (2000). Emotions and leadership: The role of emotional intelligence.

Human Relations, 53(8), 53-58

Gilley, A., McMillan, H.S., \& Gilley, J.W. (2009), Organizational change and characteristics of leadership effectiveness, Journal of Leadership and Organizational Studies, Vol. 16, No. 1, pp. 38-47.

Goleman, D.P. (1995). Emotional Intelligence: Why it Can Matter More than IQ for Character, Health, and Lifelong Achievement. New York: Bantam Books.

Fallon, H., et al. (2011), Engaging with leadership development in Irish academic libraries: some reflections of the future leaders program (FLP). The Australian Library Journal.

Foltin, A., Keller, R. (2012). Leading change with emotional intelligence. Nursing Management, 43, 20-25. doi:10.1097/01.NUMA.0000421675.33594.63

Fulton, J. (2019). 10 Interesting Characteristics of a Student Leader. Classcraft. https://www.classcraft.com/blog/characteristics-of-a-student-leader/

Hasson, G. (2012). Brilliant Emotional Intelligence: Harness the Power of Emotions, Succeed in All Areas of Your Life. Harlow: Pearson Life.

Heifetz, R. (2018). Adaptive Leadership - Know the Traits of Adaptive Leaders. Corporate Finance Institute. https://corporatefinanceinstitute.com/resources/careers/softskills/adaptive-leadership/

Humphrey, R. (2002). The many faces of emotional leadership. The Leadership Quarterly, 13(5), 493-504. http://dx.doi.org/10.1016/S1048-9843(02)00140-6

Ishmaill, I. et al. (2012). "The Role of Emotional Intelligence on Job Performance" in International Journal of Business and Social Science, Vol.3, No.1.

Kagame, P. (2012). Great Leaders are Flexible. SIGMA Assessment Systems. https://www.sigmaassessmentsystems.com/flexible-leader/. 
Koh, C. B., \& O’Higgins, E. (2018). Relationships between emotional intelligence, perceived and actual leadership effectiveness in the military context. Military Psychology, 30(1), 27 42. doi:10.1080/08995605.2017.1419021

Lavery, S. and Hine, G. (2013). Catholic School Principals: Promoting Student Leadership Catholic Education: A Journal of Inquiry and Practice, 17(1), 41-66.

Landry, L. (2019). 8 Essential Leadership Communication Skills. Harvard Business School Online. https://online.hbs.edu/blog/post/leadership-communication

Miller, K.B. (2015). The Relationship between Emotional Intelligence Behaviors and Leadership Practices among Women Leaders in Education and Business Organizations. Unpublished Ph.D. Dissertion. The Philippines: Capella University.

Moore, B. (2009). Emotional intelligence for school administrators: A priority for school reform? American Secondary Education, 37(3), 20-28.

Nabih, Y., Metwally, A.H. \& Nawar, Y. (2016). Emotional intelligence as a predictor of leadership effectiveness. The Business and Management Review, Volume 7 Number 5

Nelson, J.K., Zaccaro, S.J. \& Herman, J.L. (2010). Strategic information provision and experiental variety as tools for developing adaptive leadership skills. Consulting Psychology Journal: Practice and Research.

Obomanu, F. (2018). Emotional Intelligence: Catalyst for Leadership Effectiveness. Global Journal of Management and Business Research: A Administration and Management Type. Volume 18 Issue 6

Ocampo, J. (2019). Emotional Intelligence and Leadership Trait among Master Teachers. Mimbar Pendidikan 4(1):2503-457. DOI:10.17509/mimbardik.v4i1.16970

Poonamallee, Latha et al. (2018). "Improving Emotional Intelligence through Personality Development: The Effect of the Smart Phone Application Based Dharma Life Program on Emotional Intelligence" in Frontiers in Psychology, Volume 9.

Quismorio, E. (2020). CSC offers course on emotional intelligence. Manila Bulletin. https://mb.com.ph/2020/02/14/csc-offers-course-on-emotional-intelligence/

Raquel Gómez-Leal, Allison A. Holzer, Christina Bradley, Pablo Fernández-Berrocal \& Janet Patti (2021): The relationship between emotional intelligence and leadership in school leaders: a systematic review, Cambridge Journal of Education, DOI: 10.1080/0305764X.2021.1927987 
Reh, J. (2020). Great Leaders Know How to Be Positive. The Balance Careers. https://www.thebalancecareers.com/leaders-are-always-positive-2275805.

Root, D. (2018). Why Effective Leadership Starts with Communication. Eagle's Flight. https://www.eaglesflight.com/blog/why-effective-leadership-starts-withcommunication.

Srivastava, K. (2013). Emotional intelligence and organizational effectiveness. Industrial Psychiatry Journal, 22(2), 97-99.

Stottlemyer, B. G. (2002). An examination of emotional intelligence: Its relationship to achievement and the implications for education. Dissertation Abstracts International Section A: Humanities and Social Sciences, 63(2-A), 572.

Youssef-Morgan, C.M., \& Luthans, F. (2013). Positive leadership: Meaning and application across cultures. Organizational Dynamics, 42, 198-208. http://dx.doi. org/10.1016/j.orgdyn.2013.06.005 